\title{
ICT COMPETENCES FOR EDUCATIONAL INNOVATION: A TEACHER TRAINING PROGRAM IN COLOMBIA
}

\author{
David Castro-Garcia ${ }^{1}$, \& Fredy Andrés Olarte Dussán ${ }^{2}$ \\ ${ }^{1}$ Department of Psychology, Universidad Nacional de Colombia (Colombia) \\ ${ }^{2}$ Department of Electrical and Electronic Engineering, Universidad Nacional de Colombia (Colombia)
}

\begin{abstract}
The growing diffusion of technology in educational environments has raised the need to align Information and Communication Technologies (ICT) to the curriculum to promote innovative pedagogical practices in teachers. However, achieving this objective requires teachers to develop competencies for the effective use of these technologies. Under this scenario, the Ministry of National Education of Colombia implemented a teacher training program to strengthen six competencies associated with the use of ICT: technological, communicative, pedagogical, investigative, management, and design. The objective of the research is to understand the relevance of the program in strengthening each competence. The study analyzes the perception of a sample of 2160 beneficiary teachers of the program throughout 31 of the 32 departments that compose the country. A questionnaire was applied with 36 statements about the usefulness and use of the program for teaching practice. In general terms, the results showed that most teachers agree that the contents of the program are relevant to the development of competences. Specifically, the results suggest that technological and pedagogical competencies were favored by self-directed, cooperative, and didactic learning strategies by using ICT that promote problem-solving skills in students. The communicative competence was associated with the learning of ICT tools that allowed to systematize and communicate significant experiences. Additionally, the research competence was related to the participation in communities of practice for the collective construction of knowledge with the support of ICT, the use of the information available on the web in a critical manner and the reporting of own research results using ICT. Similarly, management competence was driven by activities that required the explanation of educational policies on and with the use of ICT. Finally, design competence was related to the planning of teaching units to improve educational practices through the combination of existing methods and ICT. Findings are discussed in terms of the importance of the training program and lifelong learning for teacher's professional development.
\end{abstract}

Keywords: ICT competences, teacher training program, professional development, lifelong learning, Colombia.

\section{Introduction}

The growing diffusion of technology in educational environments has raised the need to align Information and Communication Technologies (ICT) to the curriculum to promote innovative pedagogical practices in teachers (Vaillant, 2013). Accordingly, the Organization of Ibero-American States (OEI) has highlighted in the Educational Goals 2021 the importance to integrate ICT into schools' education plans. (OEI, 2010). However, achieving this objective requires teachers to develop competencies for the effective use of these technologies (Fernández \& Pérez, 2018).

Aware of this scenario, the Ministry of National Education (MEN, 2013) of Colombia implemented a teacher training program under a blended learning approach to strengthen six competencies associated with the use of ICT: technological, communicative, pedagogical, investigative, management, and design. The program is part of the policy to innovate in education using ICT aiming the lifelong learning for teacher's professional development. Therefore, the objective of this research is to understand the perception of teachers about the relevance of the program in strengthening each competence. 


\section{Framework}

In Colombia, the Teacher Training in ICT Use Program aims to improve the teaching skills needed to successfully use ICT in teaching-learning processes. Competence is understood as the set of knowledge, skills, attitudes, comprehensions, and cognitive, socio-affective and psychomotor dispositions. This set facilitates the flexible, effective and meaningful performance of an activity in new and challenging contexts (MEN, 2006). Based on the current competency standards for Teacher Professional Development (MEN, 2013), the six necessary competencies are defined as shown below.

- Technological competence is the ability to choose and use various technological tools in a responsible and efficient manner (including the principles that govern them).

- Communicative competence is the ability to express oneself, establish contacts and participate in virtual and audiovisual spaces through various media and managing several languages synchronously and asynchronously.

- Pedagogical competence is the ability to use ICT to strengthen teaching-learning processes, as well as to identify the achievements and limitations of the incorporation of these technologies in students and in their own professional development.

- Research competence is the ability to use ICT for the transformation of knowledge and the generation of new knowledge.

- Management competence is the ability to use ICT in the planning, organization, administration, and evaluation of effective educational processes, both in pedagogical practices and in institutional development.

- Design competence is the ability to design learning environments and develop materials and conditions necessary for effective learning in creative, critical, strategic and artistic ways.

The current competency standards for Teacher Professional Development states that each competence is evidenced in different levels (explorer, integrator, innovator), the innovative character is the desired degree. This level highlights the ability to use ICT to create educational content, to express their ideas in different spaces and through multiple communication channels, to collectively build new knowledge and to construct novel strategies that allow them to reconfigure their practice and their pedagogical knowledge. In this regard, it is worth indicating the relationship of this approach with the UNESCO ICT Competency Framework for Teachers (UNESCO, 2011). It also has three similar categories by which progress is made gradually (Technology literacy, Knowledge deepening, Knowledge creation). However, the emphasis is placed on the third category where the acquisition of knowledge is given by the ability to create new knowledge.

\section{Method}

\subsection{Participants}

The study analyzed the perception of a sample of 2160 beneficiary teachers of the program throughout 31 of the 32 departments that compose the country. $43.57 \%$ of the beneficiary teachers were men and $56.43 \%$ were women. The age range was from 18 to 71 years. Regarding academic qualification, $1.4 \%$ reported having a high school degree, $17.01 \%$ college degree, $32.87 \%$ major degree, $46.75 \%$ master's degree, $1.83 \%$ a doctoral degree, and $0.14 \%$ Postdoctoral degree. Regarding the job position, $91.83 \%$ reported being teachers, $4.08 \%$ coordinators, $1.17 \%$ rectors, and $2.92 \%$ a different job position.

\subsection{Instrument}

To identify the relevance of the content of the teacher training program, an instrument was applied that included 36 items (statements) related to the use of ICT competences in the classroom. 18 items referred to whether the content received seemed useful for their process as teachers and the other 18 items referred to whether they actually use what they learned in their respective classes. The items were multiple-choice with a single response where each teacher could grade on a Likert scale from one to four according to their level of agreement $(1=$ strongly disagree, $2=$ disagree, $3=$ agree, $4=$ strongly agree $)$ in front of each statement.

\subsection{Procedure and data analysis}

According to the information above, the response options "strongly agree" and "agree" are integrated when analyzing the results. It is considered that both response options refer to the level of agreement of the competition and only changing the intensity level between them. In this sense, the results on the relevance of the content of the teacher training program (usefulness and use) will be presented according to each competency. 


\section{Results}

The results shown in Table 1 indicate that there is a high perception of teachers about the usefulness and use of the contents of the program to improve the ICT competences in educational practices. It can be affirmed that most of the participants agree that the contents of the program are relevant to the development of each competence: design (95\%), followed by technological (94\%), pedagogical (93\%) communicative (93\%), research $(89 \%)$, and management $(84 \%)$.

The evaluation of the relevance of the content of the program allows suggesting specific connections. For example, the development of design competence was related to the creation of the planning of teaching units to improve educational practices through the combination of existing methods and ICT. Additionally, technological and pedagogical competencies were favored by self-directed, cooperative, and didactic learning strategies by using ICT that promote problem-solving skills in students. Furthermore, communicative competence was associated with the learning of ICT tools that allowed to systematize and communicate significant experiences. Moreover, the research competence was related to the participation in communities of practice for the collective construction of knowledge with the support of ICT, the use of the information available on the web in a critical way and the reporting of own research results using ICT. Finally, management competence was driven by activities that required the explanation of educational policies on and with the use of ICT.

Table 1. Teachers' perception of the relevance of the training program for the development of ICT competences.

\begin{tabular}{|lllc|}
\hline \multicolumn{1}{|c}{ Competence } & Relevance & Percentage & Average percentage \\
\hline \multirow{2}{*}{ Design } & Usefulness & $97 \%$ & $95 \%$ \\
\cline { 2 - 3 } & Use & $93 \%$ & $95 \%$ \\
\hline \multirow{2}{*}{ Technological } & Usefulness & $96 \%$ & 9 \\
\cline { 2 - 3 } & Use & $93 \%$ & $94 \%$ \\
\hline \multirow{2}{*}{ Pedagogical } & Usefulness & $95 \%$ & \multirow{2}{*}{$93 \%$} \\
\cline { 2 - 3 } & Use & $91 \%$ & \\
\hline \multirow{2}{*}{ Communicative } & Usefulness & $96 \%$ & \multirow{2}{*}{$93 \%$} \\
\cline { 2 - 3 } & Use & $91 \%$ & \\
\hline \multirow{2}{*}{ Research } & Usefulness & $90 \%$ & \multirow{2}{*}{$89 \%$} \\
\cline { 2 - 3 } \multirow{2}{*}{ Management } & Use & $87 \%$ & \multirow{2}{*}{$84 \%$} \\
\cline { 2 - 3 } & Usefulness & $88 \%$ & \\
\cline { 2 - 3 } & Use & $80 \%$ & \\
\hline
\end{tabular}

\section{Discussion}

The results of the design competence highlight the importance of creating teaching unit plans as tools to apply what has been learned in the classrooms. Products such as blogs are pedagogical creations made by teachers themselves that favor the design skills needed not only for teachers to improve didactic practices, but also to be agents and leaders of change in their communities and schools. In agreement with Clark and Mayer (2011), these creations are related to communicative competence since they function as a channel to record and store their productions (documents, notes, photographs, images), help teachers to record and follow their daily impressions, support the writing skills that any teacher should have and strengthen different channels and tools that must be used to transmit information to students in the educational context.

Additionally, technological and pedagogical competencies were favored by self-directed, cooperative, and didactic learning strategies by using ICT that promotes problem-solving skills in students. These results agree with the observations of Lu, Lajoie, \& Wiseman (2010) about the blended-learning modality. The researchers state that Computer-Supported Collaborative Learning in the blended-learning approach promotes technological and pedagogical skills. While virtual sessions support self-regulated learning processes with predesigned learning tasks and resources, and with pair scaffolding, classroom sessions favor problem-based learning processes with guidance from an expert. However, when teachers do not have the necessary skills to design and implement technology-rich learning environments, the guidance from an expert must be combined with participation in learning communities to foster a highly effective teacher professional development model (ISTE, 2011). 
In this regard, the results of this study suggest that participation in these communities may also favor the development of investigative competence. It is particularly useful for teachers to be connected with peers through networks and communities of practice where problems are shared, and solutions are collectively developed. In the words of Downes (2011), the idea of these connections is for the apprentice to understand a community of practice and to know first-hand the ways of doing what practitioners do, and through that practice, it resembles acts, thoughts, and values to the members of such a community. In this way, the connection becomes a community of educators who try to learn how they learn so that they can help their students learn with digital resources.

Finally, the results suggested that the management competence was driven by activities that required the explanation of educational policies on and with the use of ICT. However, the definition of this competence is broader, it includes the ability to use ICT in the planning, organization, administration, and evaluation of effective educational processes, both in pedagogical practices and in institutional development. Although this study shows that there is a high perception of teachers about the relevance of the program in the development of all competences, it is worth mentioning that management competence was the lowest $(84 \%)$. This result is consistent with others in which they establish that the competencies of lower valuation are all those that are related to the ability to formulate and manage projects with the use of ICT (Afanador, 2017). An alternative explanation is that it may be that teachers associate this competence with the administrative functions of the principles of the schools.

\section{Conclusions}

The latest version of The Key Competences Reference Framework by the EU defines them as a "dynamic combination of the knowledge, skills, and attitudes a learner needs to develop throughout life, starting from early age onwards. High quality and inclusive education, training and lifelong learning provide opportunities for all to develop key competences, therefore competence-oriented approaches can be used in all education, training and learning settings throughout life" (European Council, 2018, p.12). However, one of the main drawbacks related to ICT training for teachers is that they feel that they do not have spaces for early and permanent professional development (OECD, 2009). Consequently, it is in their own free time when teachers practice their ICT skills more. Additionally, only one out of three students in Europe receive classes taught by teachers with mandatory ICT training.

Furthermore, according to Clarín (2013), most primary and secondary teachers do not feel capable of teaching digital skills effectively. According to Afanador (2017), 70\% of teachers would like to learn to improve their skills in Information Technology and Communications Systems (STIC). Thus, teachers are demanding initial and ongoing training to face this challenge and improve their 21st century skills (Vuorikari et al. 2012). The question here is which ones and how they should be developed. Although there are national and international reference frameworks to define competences for training processes and evaluation systems and as an alternative for educational innovation, the reality of the current context of education is that the necessary competencies change radically due to the rapid diffusion of technology in the educational environment. The answer then is not in the ICT but in the user's own characteristics, in the generation of early and permanent spaces that encourage the development of digital skills, the articulation of ICT with the curriculum and teaching practice.

\section{References}

Afanador, H. A. (2017). Estado actual de las competencias TIC de docentes. Puente, 9(2), 23-32.

Clarín, P (2013). La apertura de la Educación. Online educar Berlin. The Largest Global E - Learning Conference for the Corporate, Education, and Public Service Sectors. News Portal.

Clark, R. C., \& Mayer, R. E. (2011). Aprendizaje digital y las Ciencias Naturales de la docencia. San Francisco, CA: Pfeiffer.

Downes, S. (07 de 01 de 2011). Connectivism and Connective Knowledge. Retrieved April 4, 2019, from http://www.downes.ca/post/54540

European Council. (2018). Council Recommendation of 22 May 2018 on key competences for lifelong learning (Text with EEA Relevance) (2018/C 189/01). Official Journal of the European Union.

Fernández, J. T., \& Pérez, K. V. P. (2018). Nuevos escenarios y competencias digitales docentes: hacia la profesionalización docente con TIC. Profesorado, Revista de Currículum y Formación del Profesorado, 22(1), 41-67.

Lu, J., Lajoie, S. P., \& Wiseman, J. (2010). Scaffolding problem-based learning with CSCL tools. International Journal of Computer-Supported Collaborative Learning, 5(3), 283-298.

MEN. (2006). Estándares Básicos de Competencias. 
MEN. (2013). Competencias TIC para el desarrollo profesional docente. Documento elaborado por la Oficina de Innovación Educativa con Uso de Nuevas Tecnologías.

OECD. (2009). Creating Effective Teaching and Learning Environments: First Results from TALIS.

OEI. (2010). Metas 2021. La educación que queremos para la generación de los bicentenarios. Documento Final. Madrid, España: Organización de Estados Iberoamericanos para la Educación, la Ciencia y la Cultura (OEI).

ISTE. (2011). Technology, Coaching and Community. Power Partners for Improved Professional Development in Primary and Secondary Education.

UNESCO. (2011). UNESCO ICT competency framework for teachers. Paris, France: UNESCO.

Vaillant, D. (2013). Programa TIC y Educación Básica: Integración de TIC en los sistemas de formación docente inicial y continua para la Educación Básica en América Latina. Fondo de las Naciones Unidas para la Infancia (UNICEF): Argentina.

Vuorikari, R., Garoia, V., Punie, Y., Cachia, R., Redecker, C., Cao, Y., \& Sloep, P. (2012). Teacher networks-Today's and tomorrow's challenges and opportunities for the teaching profession. Brussels: European Schoolnet. Germany Greece Hungary Ireland Italy Latvia Lithuania Luxembourg Malta Netherlands Poland Portugal Romania Slovakia Slovenia Spain Sweden United Kingdom non EU country. 